\title{
Long-Term Follow-Up of a Portuguese Single- Centre Cohort of Persons with Haemophilia and Hepatitis C Virus Infection
}

\author{
Tiago Pereira Guedes ${ }^{a}$ Mónica Garrido ${ }^{a}$ Ricardo Kuttner Magalhães ${ }^{a}$ \\ Teresa Moreira $^{\mathrm{a}}$ Marta Rocha ${ }^{\mathrm{a}}$ Luís Maia $^{\mathrm{a}}$ José Manuel Ferreira ${ }^{\mathrm{a}}$ \\ Sara Morais ${ }^{b}$ Isabel Pedroto ${ }^{a}$ \\ ${ }^{a}$ Gastroenterology Department, Centro Hospitalar Universitário do Porto, Porto, Portugal; \\ ${ }^{\mathrm{b}}$ Haematology Department, Centro Hospitalar Universitário do Porto, Porto, Portugal
}

\section{Keywords}

Hepatitis C, chronic · Haemophilia A · Haemophilia B .

End-stage liver disease $\cdot$ Direct-acting antivirals

\section{Abstract}

Introduction: Persons with haemophilia (PWH) used to represent a population with a high prevalence of hepatitis $C$ virus (HCV) infection due to the use of contaminated blood products. Although the goals of antiviral therapy are the same as the general population, long real-life follow-up data regarding their outcomes are still scarce. Our aim was to report the outcomes of HCV infection and the results of antiviral therapy in PWH. Methods: A retrospective analysis was performed in a single-centre cohort of $\mathrm{PWH}$ with positive $\mathrm{HCV}$ antibody. Outcomes registered were rate of spontaneous clearance of HCV, sustained virologic response (SVR) achievement, development of end-stage liver disease, and all-cause and liver-related mortality. Results: Out of 131 PWH, 73 (55.7\%) had positive HCV antibody. During a median follow-up time of 22 years, 46 patients (63.9\%) developed chronic hepatitis C, of which 16 (34.8\%) developed cirrhosis. Treatment was pursued in $34 \mathrm{PWH}$. Most $(n=32)$ were first treated with interferon (IFN)-based regimens with SVR rates of $40.6 \%$. Direct-acting antivirals were used in 14 IFN- experienced and 2 naïve patients, with an overall SVR rate of $100 \%$. Overall, 17 patients (23.3\%) died during the follow-up, only 4 related to liver disease. Of these, none had achieved SVR. Conclusions: We describe the outcomes of a cohort of Portuguese PWH and hepatitis C exposure after two decades of follow-up, with a lower mortality than previously described. Our response rates to HCV treatment were comparable to those in the general population and stress the importance of early treatment.

() 2020 Sociedade Portuguesa de Gastrenterologia Published by S. Karger AG, Basel

\section{Hepatite $C$ em pessoas com hemofilia: follow-up de longa data de uma coorte unicêntrica portuguesa}

\section{Palavras Chave}

Hepatite $C$ crónica · Antivíricos de ação direta · Doença hepática terminal · Hemofilia A · Hemofilia B

\section{Resumo}

Introdução: A população de doentes com hemofilia (DCH) representa uma população com alta prevalência de infeção pelo vírus da hepatite $\mathrm{C}(\mathrm{VHC})$, atendendo à uti- karger@karger.com www.karger.com/pjg

Karger $\stackrel{\text { ' }}{5}$

BOPEN ACCESS
(C) 2020 Sociedade Portuguesa de Gastrenterologia Published by S. Karger AG, Basel

This article is licensed under the Creative Commons AttributionNonCommercial-NoDerivatives 4.0 International License (CC BYNC-ND) (http://www.karger.com/Services/OpenAccessLicense). Usage and distribution for commercial purposes as well as any distribution of modified material requires written permission.
Tiago Pereira Guedes

Gastroenterology Department, Centro Hospitalar Universitário do Porto Largo do Prof. Abel Salazar

PT-4099-001 Porto (Portugal)

tiagoapguedes@gmail.com 
lização passada de derivados sanguíneos contaminados. Apesar de os objetivos terapêuticos nesta população serem semelhantes aos da população geral, estudos de vida real com follow-up de longa data são ainda escassos. O nosso objetivo consistiu em avaliar os outcomes infeção VHC, bem como, os resultados da terapêutica antivírica nos DCH. Métodos: Foi avaliada retrospetivamente uma coorte unicêntrica de DCH com positividade para antiVHC. Os outcomes registados foram a ocorrência de clearance espontâneo, resposta virológica sustentada (RVS), desenvolvimento de doença hepática terminal e mortalidade. Resultados: De 131 DCH, 73 (55.7\%) apresentavam positividade para o anticorpo VHC. Durante um follow-up médio de 22 anos, 46 doentes (63.9\%) desenvolveram hepatite crónica C, 16 (34.8\%) dos quais com desenvolvimento de cirrose. Trinta e quatro DCH foram tratados, a maioria $(n=32)$ exposta previamente a regimes baseados no interferão (IFN) com RVS de $40.6 \%$. Antivíricos de ação direta foram utilizados em 14 doentes experimentados a IFN e 2 naïves com uma taxa de RVS geral de $100 \%$. Morte foi observada em 17 doentes (23.3\%), apenas 4 relacionadas à doença hepática. Destes nenhum tinha atingido RVS. Conclusões: Descrevemos os outcomes de uma coorte portuguesa de DCH e VHC após duas décadas de follow-up, mostrando uma mortalidade inferior à previamente descrita. As taxas de RVS mostradas foram comparáveis com as da população geral salientando a importância do tratamento precoce.

C 2020 Sociedade Portuguesa de Gastrenterologia Publicado por S. Karger AG, Basel

\section{Introduction}

Hepatitis C virus (HCV) infects over 160 million people worldwide and is one of the main causes of chronic hepatitis and progressive liver damage, inflicting a higher risk for cirrhosis, end-stage liver disease (ESLD), hepatocellular carcinoma (HCC), and death [1]. Haemophilia is a hereditary X-linked disorder caused by total or partial deficiency of coagulation factors VIII (haemophilia A) and IX (haemophilia B) [2, 3 ]. They represent two of the most frequent hereditary bleeding disorders, with its prevalence estimated in 1-9/100,000 males [4]. The World Federation of Haemophilia 2017 report reveals that out of nearly 315,000 people with bleeding disorders, 196,700 are diagnosed with haemophilia, with Portugal contributing 705 cases (541 haemophilia A; 112 haemophilia B; 52 haemophilia type unknown) [5].
The advent of intravenous replacement of clotting factors radically improved the management of bleeding episodes, quality of life, and survival of these patients $[6,7]$. Despite this improvement in care, the majority of severe patients treated with coagulation factors before the existence of viral inactivation procedures and the introduction of universal HCV screening in the 1990s were infected with HCV [8-14]. Progression to ESLD in persons with haemophilia (PWH) infected with HCV is believed to be similar to that seen in the general population [15].

The main goal of antiviral therapy in PWH is the same as for the general population, aiming to achieve sustained virologic response (SVR) and to prevent disease progression and liver-related complications [15]. Previous therapies based on interferon (IFN) had low efficacy, with SVR rates ranging from 50 to $60 \%$ [16], with major side effects and poor tolerability. Since 2014 several direct-acting antivirals (DAA) have been approved, leading to higher SVR rates of up to $100 \%$ with more favourable tolerability and safety profiles. Recommendations for antiviral treatment in PWH are the same as for non-haemophiliacs [15], despite limited clinical data regarding treatment outcomes on this subgroup of patients.

Our aim was to report the natural outcomes of HCVinfected PWH and the results of DAA therapy in a singlecentre cohort of patients with haemophilia.

\section{Material and Methods}

\section{Patients and Data Collection}

We performed a retrospective, single-centre study, including all PWH with positive HCV antibody, followed in our institution from January 1995 to December 2017. Data from medical records related to this period were retrieved. Patients were classified according to type and severity of haemophilia. First exposure to blood products was recorded and assumed as the probable date of infection. The severity of haemophilia was classified as mild (5$40 \%$ of normal factor level), moderate (1-5\% of normal factor level), or severe ( $<1 \%$ of normal factor level) [17]. Status regarding $\mathrm{HBV}$ and HIV infection were collected. HCV infection was characterized by HCV genotype, duration of infection (difference between probable date of infection and the end of treatment or follow-up), and type and duration of antiviral treatment used. Registered outcomes were rate of spontaneous clearance of $\mathrm{HCV}$ (anti-HCV positive with persistently negative viremia); clinical, analytical, and/or imagiological diagnosis of cirrhosis; SVR achievement; occurrence of HCC or variceal haemorrhage; allcause and liver-related mortality.

The study was approved by the local medical ethics committee.

Statistical Analysis

Statistical analysis was performed using the IBM Statistical Package for Social Sciences 25.0 (IBM Corp., Armonk, NY, USA).
Pereira Guedes et al. 
Table 1. Baseline patient characteristics

\begin{tabular}{lc}
\hline Age, years & $51.0 \pm 12.8$ \\
Male sex & $73 / 73(100)$ \\
Haemophilia type & \\
Haemophilia A & $64 / 73(87.7)$ \\
Haemophilia B & $9 / 73(12.3)$ \\
Haemophilia severity & \\
Mild & $15 / 73(20.5)$ \\
Moderate & $24 / 73(32.9)$ \\
Severe & $34 / 73(46.6)$ \\
Co-infections & \\
HIV & $17 / 71(23.9)$ \\
HBV & $3 / 55(5.45)$ \\
HBV exposure & $34 / 59(57.6)$ \\
HCV & \\
Age at infection, years & $5.00(2.00-14.0)$ \\
Spontaneous clearance & $26 / 72(36.1)$ \\
Chronic infection & $46 / 72(63.9)$ \\
Genotype 1a & $15 / 40(37.5)$ \\
Genotype 1b & $16 / 40(40.0)$ \\
Genotype 2 & $2 / 40(5.00)$ \\
Genotype 3a & $7 / 40(17.5)$ \\
Duration of HCV infection, years & $36.1 \pm 11.0$ \\
\hline
\end{tabular}

Data are presented as mean $\pm \mathrm{SD}, n(\%)$, or median (IQR). HBV, hepatitis $\mathrm{B}$ virus; $\mathrm{HCV}$, hepatitis $\mathrm{C}$ virus; $\mathrm{HIV}$, human immunodeficiency virus.

Categorical variables were presented as frequencies and percentages, and continuous variables as means and standard deviation (SD) or medians and interquartile ranges (IQR) for variables with skewed distributions. Differences between groups were evaluated with Pearson $\chi^{2}$ test or Fischer's exact test for categorical variables, as appropriate, and the Student $t$ test for continuous variables. Variables with a significant $p$ value in univariate analysis were included in the multivariable analysis (binary logistic regression). Statistical significance was set at $p$ value $<0.05$.

\section{Results}

\section{Patient Population}

From 131 PWH, 73 (55.7\%) had a positive hepatitis C antibody, all male gender and with a median age at the end of follow-up of 51 years (SD 12.8). From the 73 patients, one was lost to follow-up. The baseline characteristics of the patients are shown in Table 1 . The majority (87.6\%) was diagnosed with haemophilia A, with $46.6 \%$ presenting a severe disease. The median age for first exposure to blood factors was 5 years (IQR 2.00-14.0), with $28.8 \%$ being exposed before the age of 2 years. Ergo, HCV duration of infection was assumed to be approximately 36.1 years (SD 11.0). Co-infection with HIV was present in $23.9 \%(n=17)$, and $5.45 \%(n=3)$ were HBsAg positive. Spontaneous clearance of HCV occurred in $36.1 \%$ ( $n=$

Follow-Up of a Cohort of Persons with Haemophilia and HCV Infection

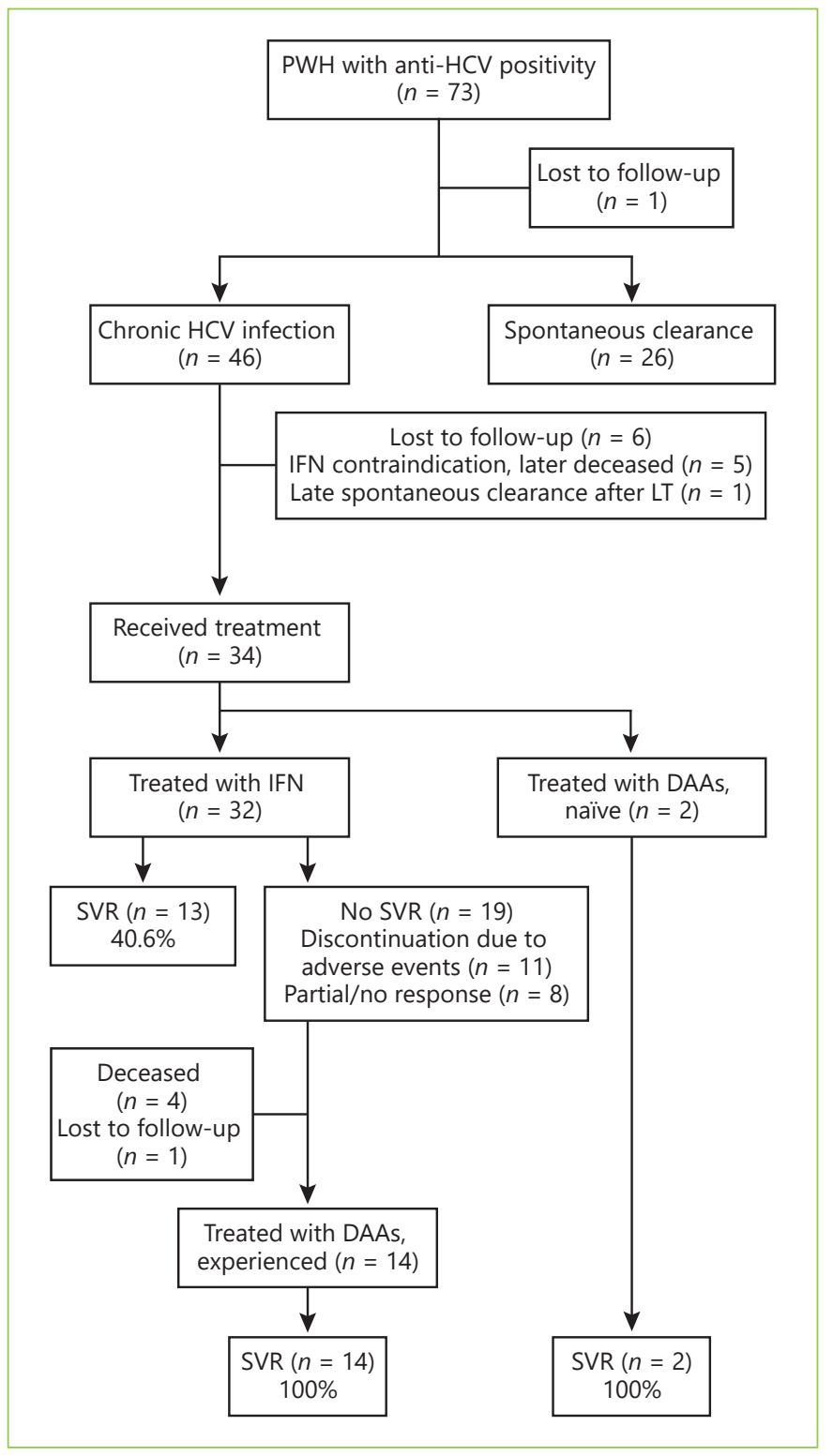

Fig. 1. Summary of treatment outcomes in $\mathrm{PWH}$ with chronic $\mathrm{HCV}$ infection. HCV, hepatitis $\mathrm{C}$ virus; DAAs, direct-acting antivirals; IFN, interferon; LT, liver transplant; SVR, sustained virologic response; $\mathrm{PWH}$, persons with haemophilia.

26), with the remaining 63.9\% $(n=46)$ developing chronic hepatitis C. Of these, HCV genotype 1 was the most common $(n=31,77.5 \%)$.

\section{Treatment}

In our cohort, 34 (out of 46) patients with chronic hepatitis $\mathrm{C}$ were treated as shown in Figure 1. Most patients were firstly treated with IFN-based regimens $(n=32)$ 
Table 2. Summary of patient characteristics and treatment outcomes in haemophilic patients with chronic HCV infection treated with DAAs

\begin{tabular}{rllllllll}
\hline $\begin{array}{l}\text { Patient } \\
\text { No. }\end{array}$ & Age & Haemophilia & Severity & Genotype & F3/F4 & IFN & DAA & $\begin{array}{l}\text { Duration, } \\
\text { SVR 12 } \\
\text { weeks }\end{array}$ \\
\hline 1 & 48 & A & Severe & $1 \mathrm{a}$ & - & $\checkmark$ & SOF/LDV & 12 \\
2 & 72 & A & Mild & - & $\checkmark$ & $\checkmark$ & SOF/LDV & 12 \\
3 & 53 & A & Mild & $1 \mathrm{~b}$ & $\checkmark$ & - & SOF/LDV & 12 \\
4 & 49 & A & Severe & $1 \mathrm{a}$ & - & $\checkmark$ & SOF/LDV & 12 \\
5 & 47 & B & Mild & $1 \mathrm{~b}$ & - & $\checkmark$ & SOF/LDV & 12 \\
6 & 43 & A & Moderate & $1 \mathrm{a}$ & - & $\checkmark$ & SOF/LDV & 12 \\
7 & 72 & A & Moderate & $1 \mathrm{a}$ & - & $\checkmark$ & SOF/LDV & 12 \\
8 & 57 & A & Severe & $1 \mathrm{a}$ & $\checkmark$ & - & OBV/PTV/r+DSV & 12 \\
9 & 54 & A & Severe & $1 \mathrm{~b}$ & $\checkmark$ & $\checkmark$ & SOF/LDV+RBV & 24 \\
10 & 59 & A & Moderate & $1 \mathrm{~b}$ & $\checkmark$ & $\checkmark$ & SOF/LDV & 24 \\
11 & 51 & A & Mild & $3 \mathrm{a}$ & $\checkmark$ & $\checkmark$ & SOF/LDV & 24 \\
12 & 43 & A & Moderate & $1 \mathrm{a}$ & - & $\checkmark$ & SOF/LDV & 12 \\
13 & 81 & A & Mild & $1 \mathrm{~b}$ & $\checkmark$ & $\checkmark$ & EBR/GRZ & 12 \\
14 & 56 & A & Moderate & 2 & $\checkmark$ & $\checkmark$ & SOF+RBV & 16 \\
15 & 63 & A & Mild & $1 \mathrm{~b}$ & $\checkmark$ & $\checkmark$ & SOF/LDV & 24 \\
16 & 39 & A & Severe & $1 \mathrm{~b}$ & $\checkmark$ & $\checkmark$ & SOF/LDV & 12 \\
\hline
\end{tabular}

HCV, hepatitis C virus; DAA, direct-acting antiviral; DSV, dasabuvir; EBR, elbasvir; GRZ, grazoprevir; F3/F4, fibrosis stage 3 or 4 (advanced liver disease); IFN, interferon experienced; LDV, ledipasvir; OBV, ombitasvir; PTV, paritaprevir; r, ritonavir; RBV, ribavirin; SOF, sofosbuvir; SVR, sustained virologic response.

Table 3. Clinical outcomes in patients with haemophilia and HCV exposure by HCV status

\begin{tabular}{lrrrr}
\hline & $\begin{array}{l}\text { Total } \\
(n=73)\end{array}$ & $\begin{array}{l}\text { Spontaneous } \\
\text { clearance }(n=26)\end{array}$ & $\begin{array}{l}\text { Chronic infection } \\
(n=46)\end{array}$ & $p$ value \\
\hline Liver cirrhosis & $16(21.9)$ & $0(0.00)$ & $16(34.8)$ & 0.001 \\
Hepatocellular carcinoma & $2(2.74)$ & $0(0.00)$ & $2(4.35)$ & 0.532 \\
Liver transplant & $3(4.11)$ & $0(0.00)$ & $3(6.52)$ & 0.183 \\
Death, overall* & $17(23.3)$ & $7(26.9)$ & $9(19.6)$ & 0.553 \\
$\quad$ Liver-related & $4(5.48)$ & $0(0.00)$ & $4(8.70)$ & - \\
$\quad 2(2.74)$ & - & $2(4.35)$ & - \\
$\quad$ Variceal haemorrhage & $1(1.37)$ & - & $1(2.17)$ & - \\
$\quad$ Sepatocellular carcinoma & $1(1.37)$ & - & $3(6.52)$ & - \\
$\quad$ Haemophis & $7(9.59)$ & $4(15.4)$ & $1(2.17)$ & - \\
Acquired immunodeficiency virus & $2(2.74)$ & $1(3.85)$ & $47.4 \pm 17.0$ & 0.758 \\
$\quad$ Not reported & $4(5.48)$ & $3(11.5)$ & $50.2 \pm 14.4$ & \\
Age at death, years & $48.4 \pm 15.4$ & & & - \\
\hline
\end{tabular}

Data are presented as $n(\%)$ or mean \pm SD. * One patient: missing information. HCV, hepatitis C virus.

with SVR rates of $40.6 \%$. Eleven patients discontinued the treatment due to adverse events and 8 due to partial or no response. Treatment with DAA was pursued in 14 IFNexperienced and 2 naïve patients. The most common DAA-treatment regimen was the combination of sofosbuvir and ledipasvir for 12 to 24 weeks. The overall SVR rates were $100 \%$ (Table 2 ).

\section{Clinical Outcomes}

\section{Cirrhosis and ESLD}

From first blood products exposure, a median followup time of 40 years (IQR 34.5-45) was observed. During this period, cirrhosis developed in 16 patients, corresponding to $34.8 \%$ and an incidence rate of 0.9 per 100 patient-years. The association of chronic HCV infection 
Table 4. Clinical outcomes in patients with chronic HCV infection by HCV infection status

\begin{tabular}{llllr}
\hline & $\begin{array}{l}\text { Total } \\
(n=46)\end{array}$ & $\begin{array}{l}\text { No treatment/ } \\
\text { no SVR }(n=17)\end{array}$ & $\begin{array}{l}\text { SVR } \\
(n=29)\end{array}$ & $p$ value \\
\hline Liver cirrhosis & $16(34.8)$ & $8(47.1)$ & $8(27.6)$ & 0.109 \\
Hepatocellular carcinoma & $2(4.35)$ & $1(5.88)$ & $1(3.45)$ & 1.000 \\
Liver transplant & $3(6.52)$ & $1(5.88)$ & $2(6.90)$ & 1.000 \\
Death, overall & $9(19.6)$ & $9(52.2)$ & $0(0.00)$ & $<0.000$ \\
\hline
\end{tabular}

Data are presented as $n(\%) . \mathrm{HCV}$, hepatitis C virus; SVR, sustained virologic response.

with the development of cirrhosis was statistically significant $(p=0.003)$ (Table 3). HBV exposure (anti-HBc+) and HBV (AgHBs+) and HIV infection were all associated with cirrhosis development, although without statistical significance ( $p=0.059, p=0.053, p=0.056$, respectively). From the 16 cirrhotic patients, 2 complicated with HCC and 3 were transplanted successfully due to hepatic decompensation (Table 3).

\section{Mortality}

Overall, 17 patients died during the follow-up period (23.3\%) with an annual mortality rate of $0.68 \%$ per year. The mean age at the time of death was 48.4 years (SD 15.4 years). The cause of death was attributable to liver disease in 4 patients (variceal bleeding $n=2$; HCC $n=1$; sepsis $n=1$ ), representing $23.5 \%$ of all deaths. All haemophiliarelated deaths $(n=7,41.2 \%)$ were the consequence of intracranial haemorrhage. HIV evolution to acquired immunodeficiency syndrome was responsible for 2 deaths $(11.8 \%)$. Overall, higher mortality rates were observed in severe haemophilia (39.4 vs. $10.3 \%, p=0.004$ ), in chronic HBV-infected patients (AgHBs+) (66.7 vs. $5.8 \%, p=$ 0.019 ), and in HIV-positive patients (64.7 vs. $11.3 \%, p<$ 0.001 ), as well as in cirrhotic patients (43.8 vs. $17.9 \%, p=$ 0.046 ), more evident for those with portal hypertension (50.0 vs. $12.5 \%, p=0.015)$ and patients who had not achieved SVR ( 100 vs. $0 \%, p<0.001)$. However, none of these variables was found significant on multivariate analysis.

The number and the mean age at the time of death were not significantly different between the spontaneous clearance and chronic HCV groups (Table 3). In the chronic HCV group, all deaths $(n=9)$ occurred in patients who had not achieved SVR $(\mathrm{p}<0.001)$ (Table 4). Only 1 death occurred in 2017, with all the others occurring before 2010 and DAA introduction.

Follow-Up of a Cohort of Persons with

Haemophilia and HCV Infection

\section{Discussion}

The availability of clotting factors for PWH significantly enhanced the management of bleeding episodes, the safety of invasive procedures, their quality of life, and overall survival $[6,7,18,19]$. Before the 1990s, such factors did not undergo viral inactivation procedures, which led to HCV transmission to haemophiliac patients [20, $21]$. Besides the inexistence of viral inactivation mechanisms, the concentrates were prepared from large pools of plasma, and so it is agreed that virtually all patients treated with these products were infected with $\mathrm{HCV}$ at the time of the first infusion $[8,22]$. The haemophiliac population represents the possibility of getting as close as possible to the natural history of HCV infection. In fact, this natural history is intricate to study because of the dissimilar way of contracting the disease in different patients, the difficulty in determining the moment of infection, the general lack of compliance during follow-up, and the necessity of a long period of time to assess a disease with such a slow progression. Our patients represent an exceptional model to study the natural course of this infection. They are a homogeneous group of people, with the same gender, with the same route of infection acquisition, and in whom we can reliably define the date of infection. They also have a long duration of infection, allowing us to get access to the true natural history of this disease.

Seroprevalence of anti-HCV in the Portuguese haemophiliac population is largely unknow. Data from our centre reveals a decreasing seroprevalence over time, with $62 \%$ of PWH being seropositive in 1990, 51.1\% in 2000 [23], and 32,3\% currently (unpublished data). Rocha et al. [24] reported positivity for anti-HCV in $21.4 \%$ of the patients treated for haemophilia at another tertiary centre between 2011 and 2013. Before HCV direct screening measures were established, $80 \%$ of PWH experienced chronic hepatitis $\mathrm{C}$ and about $20 \%$ progressed to liver cir-

GE Port J Gastroenterol 2021;28:79-86 DOI: $10.1159 / 000510023$ 
rhosis within 30 years [25]. In our cohort, spontaneous clearance of $\mathrm{HCV}$ occurred in $35 \%$ of the patients, which stands between values of $20-40 \%$ reported in some studies [26, 27]. Also, approximately $30 \%$ of patients evolved to cirrhosis [28]. This slightly different value can be explained by the longer follow-up of our study as well by the drop-out rate in which we could have lost some patients that would not progress to cirrhosis. As a fact, our lostto-follow-up population $(n=8)$ consisted of a $\mathrm{PWH} /$ $\mathrm{HCV}+$ with no other information regarding evolution of $\mathrm{HCV}$ infection, patients who were not proposed for IFN therapy $(n=6)$, and a PWH treated with IFN and lost to follow-up without any subsequent information. Our data is also compatible with that of other cohorts [29], showing a lower mean age of infection than that of the general population at risk for $\mathrm{HCV}$ due to haemophilia treatment with inactivated plasma products from childhood.

Patients with spontaneous clearance of the virus were also included, eliminating selection bias that may occur when the exclusion of such patients conducts to worse prognosis and outcome of the disease.

Treatment provides the best weapon to change the natural history of HCV infection. The effectiveness of IFN regimens appears to be similar to the general population, with overall SVR rates reaching 60\% [16]. Higher rates of SVR are observed in HIV-negative and in the treatment of naïve haemophiliac patients, ranging from $45 \%$ for genotype 1 to $79 \%$ for non- 1 genotype [30]. The SVR rate of $41 \%$ observed in our cohort is in accordance with these data. The slightly lower value could be explained by treatment discontinuation secondary to side effects and a predominance of poor prognostic factors of our patients such as male gender, genotype 1, and long duration of infection.

With the development and approval of DAA drugs, the treatment of HCV has witnessed a true revolution, with patients achieving higher rates of cure with significant less adverse events and shorter time regimens [29]. Initial studies on DAAs did not include patients with special comorbidities, as real-life studies lacked significant data for patients with inherited haemorrhagic disorders [31]. IFN- and RBV-free regimens with LDV/SOF resulted in early HCV suppression that continued throughout the duration of treatment and post-treatment [32]. Our cohort of patients treated with DAA was composed of IFN-experienced patients in $87.5 \%$, and $62.5 \%$ had signs of advanced liver disease. Our SVR rates results were excellent (100\%) and comparable to other cohorts results $[29,33]$. Stedman et al. [33] studied the effect of SOF/ LDV + RBV on 14 haemophiliacs, 2 von Willebrand and 1 patient with factor XIII deficiency. All patients achieved SVR12 with no safety concerns associated with the patients' underlying bleeding disorders [33]. Walsh et al. [34] also concluded that SOF/LDV for patients with HCV genotype 1 or 4 infection or SOF+RBV for patients with genotype 2 or 3 infection was highly effective and well tolerated among those with inherited bleeding disorders. Nagao and Hanabusa [35] studied 43 patients with haemophilia with genotype 1 or $4 \mathrm{HCV}$ treated with SOF/ LDV and showed effectiveness and safeness, but with SVR in patients with cirrhosis being lower than that in the non-cirrhotic group, stressing the need for treatment as early as possible, ideally before the onset of cirrhosis. Papadopoulos et al. [31] summarized all available DAA studies in inherited bleeding disorders, showing an overall SVR $>95 \%$ with SOF/LDV regimens.

Despite these encouraging results with DAAs, in our cohort, only 34 out of 46 patients with chronic HCV $(73.9 \%)$ received treatment and only 29 of these patients achieved SVR (85.3\%) overall. This was mainly a result of patients lost to follow-up $(n=8)$ or IFN contraindication $(n=5)$ and adverse events/no response $(n=4)$ in patients who did not survive to meet the DAA era.

Mortality of $\mathrm{PWH}$ is known to be 2-5 times higher than that of the general population [36], which can reach 16 times higher in the setting of cirrhosis and HCC [10]. Some studies also showed a significant proportion of ESLD in a cohort of $863 \mathrm{HCV}$-infected patients with inherited bleeding disorders, stressing out HCC as an increasing problem $[37,38]$. In our cohort, we only found differences in mortality between the chronically infected patients with or without SVR. This probably reflects the avoidance of progression to ESLD. The mortality rate in our cohort was $23.3 \%$, with its main cause related to bleeding events, which could be explained by the relatively young age at the time of death and higher proportion of patients with severe haemophilia. Besides haemophilia severity, we also observed a higher mortality rate in $\mathrm{HBV} / \mathrm{HIV}$ co-infection and in cirrhotic patients. Our global mortality rate is in line with a 10 -year survival pointed out between $82.1-95.3 \%$ for PWH mono- or coinfected with HIV [39]. Of note, only 1 death occurred after DAA introduction, for which no conclusions can be drawn on the effect of DAA treatment on PWH survival, although a reduced mortality in this population with SVR would be expected as compared to other populations (including those with cirrhosis) who attained SVR.

Our study has some limitations. Firstly, it was performed in a single tertiary centre and a small patient population was included. Secondly, it was retrospective in na-
Pereira Guedes et al. 
ture and a significant number of patients were lost to follow-up, meaning there are some missing data and the quality of data may be suboptimal. Also, information about alcohol consumption was not available.

However, our study has also a few strengths. Considering the rarity of haemophilia in the general population, we have included a representative sample of Portuguese PWH, with a notable follow-up of 22 years and an approximate 36 years of $\mathrm{HCV}$ infection evolution, necessary to study the occurrence of some of our outcomes. Also, this is the first study evaluating the efficacy of hepatitis $\mathrm{C}$ treatment and clinical outcomes in haemophiliac patients of the Portuguese population.

In conclusion, this study describes (1) the natural history of a cohort of 73 Portuguese PWH with hepatitis C exposure after two decades of follow-up, (2) hepatitis C treatment results with a special focus on direct antiviral agents, and (3) clinical outcomes of these patients. It corroborates evolution to chronic hepatitis $\mathrm{C}$ infection in $63.9 \%$ of the patients and progression to liver cirrhosis in $34.8 \%$ of them. IFN-based regimens achieved SVR rates of $40.6 \%$, probably conditioned by poor prognostic factors of our patients such as male gender, genotype 1 predominance, and long duration of infection, while DAAs achieved an outstanding 100\% SVR rate despite most of the patients being IFN-experienced and having advanced liver disease. We reported an overall mortality rate of $23.3 \%$, lower than previously described. Of these, only $23.5 \%$ were related to liver disease and all of them occurred in chronic hepatitis $\mathrm{C}$ patients who had not achieved SVR. Our results demonstrate response rates to $\mathrm{HCV}$ treatment in haemophilia patients comparable to those in the general population and stress the importance of early treatment to avoid chronic liver disease progression as well as related morbidity and mortality. DAAs might represent one of the long-awaited shifts in the care of PWH.

\section{Statement of Ethics}

The study reported was approved by the local medical ethics committee. Patient consent statement and permission to reproduce material from other sources are not applied.

\section{Conflict of Interest Statement}

Partial data of this work was already published as a form of letter to the editor. There is no conflict of interest to disclose.

\section{Funding Sources}

There are no funding sources to disclose.

\section{Author Contributions}

T.P.G., M.G., R.K.M., and T.M. performed the research. J.M.F., S.M., and I.P. designed the research study. T.P.G. and M.G. analyzed the data and wrote the paper. M.R. and L.M. contributed to data interpretation. All authors reviewed the final manuscript.

\section{References}

1 Lavanchy D. Evolving epidemiology of hepatitis $C$ virus. Clin Microbiol Infect. $2011 \mathrm{Feb}$; 17(2):107-15.

2 White GC 2nd, Rosendaal F, Aledort LM, Lusher JM, Rothschild C, Ingerslev J; Factor VIII and Factor IX Subcommittee. Definitions in hemophilia. Recommendation of the scientific subcommittee on factor VIII and factor IX of the scientific and standardization committee of the International Society on Thrombosis and Haemostasis. Thromb Haemost. 2001 Mar;85(3):560.

3 Franchini M, Favaloro EJ, Lippi G. Mild hemophilia A. J Thromb Haemost. 2010 Mar; 8(3):421-32.

4 Hemophilia. Orphanet encyclopedia, May, 2009. https://www.orpha.net/consor/cgi-bin/ OC_Exp.php?Lng=EN\&Expert $=448$

5 Hemophilia W. World Federation of Hemophilia Report On The Annual Global Survey 2017. World Federation of Hemophilia; 2018.
6 Rosendaal FR, Smit C, Briët E. Hemophilia treatment in historical perspective: a review of medical and social developments. Ann Hematol. 1991 Feb;62(1):5-15.

7 Larsson SA. Life expectancy of Swedish haemophiliacs, 1831-1980. Br J Haematol. 1985 Apr;59(4):593-602.

8 Fletcher ML, Trowell JM, Craske J, Pavier K, Rizza CR. Non-A non-B hepatitis after transfusion of factor VIII in infrequently treated patients. Br Med J (Clin Res Ed). 1983 Dec; 287(6407):1754-7.

9 Kernoff PB, Lee CA, Karayiannis P, Thomas HC. High risk of non-A non-B hepatitis after a first exposure to volunteer or commercial clotting factor concentrates: effects of prophylactic immune serum globulin. Br J Haematol. 1985 Jul;60(3):469-79.
10 Darby SC, Ewart DW, Giangrande PL, Spooner RJ, Rizza CR, Dusheiko GM, et al. Mortality from liver cancer and liver disease in haemophilic men and boys in UK given blood products contaminated with hepatitis C. UK Haemophilia Centre Directors' Organisation. Lancet. 1997 Nov;350(9089):1425-31.

11 Posthouwer D, Makris M, Yee TT, Fischer K, van Veen JJ, Griffioen A, et al. Progression to end-stage liver disease in patients with inherited bleeding disorders and hepatitis C: an international, multicenter cohort study. Blood. 2007 May; 109(9):3667-71.

12 Seeff LB. Natural history of chronic hepatitis C. Hepatology. 2002 Nov;36(5 Suppl 1):S3546.

13 Yee TT, Griffioen A, Sabin CA, Dusheiko G, Lee CA. The natural history of HCV in a cohort of haemophilic patients infected between 1961 and 1985. Gut. 2000 Dec;47(6):845-51.
Follow-Up of a Cohort of Persons with Haemophilia and HCV Infection
GE Port J Gastroenterol 2021;28:79-86 DOI: $10.1159 / 000510023$ 
14 Kernoff PB, Miller EJ, Savidge GF, Machin SJ, Dewar MS, Preston FE. Reduced risk of nonA, non-B hepatitis after a first exposure to 'wet heated' factor VIII concentrate. Br J Haematol. 1987 Oct;67(2):207-11.

15 Pawlotsky JM, Negro F, Aghemo A, Berenguer M, Dalgard O, Dusheiko G, et al. EASL recommendations on treatment of hepatitis $\mathrm{C}$ 2018. J Hepatol. 2018;69(2):461-511.

16 Posthouwer D, Mauser-Bunschoten EP, Fischer K, Makris M. Treatment of chronic hepatitis $\mathrm{C}$ in patients with haemophilia: a review of the literature. Haemophilia. 2006 Sep; 12(5):473-8.

17 Srivastava A, Brewer AK, Mauser-Bunschoten EP, Key NS, Kitchen S, Llinas A, et al.; Treatment Guidelines Working Group on Behalf of The World Federation Of Hemophilia. Guidelines for the management of hemophilia. Haemophilia. 2013 Jan;19(1):e1-47.

18 Makris M, Preston FE, Triger DR, Underwood JC, Choo QL, Kuo G, et al. Hepatitis C antibody and chronic liver disease in haemophilia. Lancet. 1990 May;335(8698):1117-9.

19 Lee CA. Hemophilia complications. Hepatitis $\mathrm{C}$ infection and its management. Haemophilia. 2000 Jul;6 Suppl 1:133-7.

20 Morfini M, Mannucci PM, Ciavarella N, Schiavoni M, Gringeri A, Rafanelli D, et al. Prevalence of infection with the hepatitis $C$ virus among Italian hemophiliacs before and after the introduction of virally inactivated clotting factor concentrates: a retrospective evaluation. Vox Sang. 1994;67(2):178-82.

21 Brettler DB, Alter HJ, Dienstag JL, Forsberg $A D$, Levine PH. Prevalence of hepatitis $\mathrm{C}$ virus antibody in a cohort of hemophilia patients. Blood. 1990 Jul;76(1):254-6.

22 Franchini M, Rossetti G, Tagliaferri A, Capra F, de Maria E, Pattacini C, et al. The natural history of chronic hepatitis $\mathrm{C}$ in a cohort of HIV-negative Italian patients with hereditary bleeding disorders. Blood. 2001 Sep;98(6): 1836-41.

23 Morais S, Campos M, Pedroto I, Justiça B. Treatment of hepatitis $C$ infection in patients with inherited bleeding disorders. Haemophilia. 2002;8:530-1.
24 Rocha P, Carvalho M, Lopes M, Araújo F. Costs and utilization of treatment in patients with hemophilia. BMC Health Serv Res. 2015 Oct;15(1):484.

25 Tagliaferri A, Rivolta GF, Iorio A, Oliovecchio E, Mancuso ME, Morfini M, et al.; Italian Association of Hemophilia Centers. Mortality and causes of death in Italian persons with haemophilia, 1990-2007. Haemophilia. 2010 May;16(3):437-46.

26 Simanis R, Lejniece S, Sochnevs A, Eglite J, Chernevska G, Kovalova Z, et al. Natural clearance of hepatitis $C$ virus in hemophilia patients. Medicina (Kaunas). 2008;44(1):1521.

27 Zhang M, Rosenberg PS, Brown DL, Preiss L, Konkle BA, Eyster ME, et al.; Second Multicenter Hemophilia Cohort Study. Correlates of spontaneous clearance of hepatitis $\mathrm{C}$ virus among people with hemophilia. Blood. 2006 Feb;107(3):892-7.

28 Ferenci P, Ferenci S, Datz C, Rezman I, Oberaigner W, Strauss R. Morbidity and mortality in paid Austrian plasma donors infected with hepatitis $\mathrm{C}$ at plasma donation in the 1970s. J Hepatol. 2007 Jul;47(1):31-6.

29 Lee HW, Yoo KY, Won JW, Kim HJ. Direct acting antiviral agents in Korean patients with chronic hepatitis $\mathrm{C}$ and hemophilia who are treatment-naïve or treatment-experienced. Gut Liver. 2017 Sep;11(5):721-7.

30 Franchini M, Mengoli C, Veneri D, Mazzi R, Lippi G, Cruciani M. Treatment of chronic hepatitis $\mathrm{C}$ in haemophilic patients with interferon and ribavirin: a meta-analysis. J Antimicrob Chemother. 2008 Jun;61(6):1191200.

31 Papadopoulos N, Argiana V, Deutsch M. Hepatitis $\mathrm{C}$ infection in patients with hereditary bleeding disorders: epidemiology, natural history, and management. Ann Gastroenterol. 2018 Jan-Feb;31(1):35-41.
32 Younossi ZM, Stepanova M, Marcellin P, Afdhal N, Kowdley KV, Zeuzem S, et al. Treatment with ledipasvir and sofosbuvir improves patient-reported outcomes: results from the ION-1, -2 , and -3 clinical trials. Hepatology. 2015 Jun;61(6):1798-808

33 Stedman CA, Hyland RH, Ding X, Pang PS, McHutchison JG, Gane EJ. Once daily ledipasvir/sofosbuvir fixed-dose combination with ribavirin in patients with inherited bleeding disorders and hepatitis $\mathrm{C}$ genotype 1 infection. Haemophilia. 2016 Mar;22(2):2147.

34 Walsh CE, Workowski K, Terrault NA, Sax PE, Cohen A, Bowlus CL, et al. Ledipasvirsofosbuvir and sofosbuvir plus ribavirin in patients with chronic hepatitis $\mathrm{C}$ and bleeding disorders. Haemophilia. 2017 Mar;23(2): 198-206.

35 Nagao A, Hanabusa H. Brief report: the impact of ledipasvir/sofosbuvir on HIV-positive and HIV-negative Japanese hemophilia patients with 1, 4, and mixed-genotype HCV. J Acquir Immune Defic Syndr. 2017 Apr;74(4): $418-22$.

36 Plug I, Van Der Bom JG, Peters M, MauserBunschoten EP, De Goede-Bolder A, Heijnen $\mathrm{L}$, et al. Mortality and causes of death in patients with hemophilia, 1992-2001: a prospective cohort study. J Thromb Haemost. 2006 Mar;4(3):510-6.

37 Fransen van de Putte DE, Makris M, Fischer K, Yee TT, Kirk L, van Erpecum KJ, et al. Long-term follow-up of hepatitis $\mathrm{C}$ infection in a large cohort of patients with inherited bleeding disorders. J Hepatol. 2014 Jan;60(1): 39-45.

38 Eyster ME, Kong L, Li M, Schreibman IR. Long term survival in persons with hemophilia and chronic hepatitis C: 40 year outcomes of a large single center cohort. Am J Hematol. 2016 Sep;91(9):E335-40.

39 Maor Y, Schapiro JM, Bashari D, Martinowitz U. Survival of hepatitis C-infected haemophilia patients is predicted by presence of cirrhosis but not by anti-viral treatment. Ann Hepatol. 2014 Nov-Dec;13(6):753-61. 